\title{
PENGEMBANGAN KETERAMPILAN BERFIKIR KRITIS SISWA MELALUI PEMBELAJARAN IPS MI
}

\author{
Nurlaili Dina Hafni, Institut Agama Islam Nahdlatul Ulama (IAINU) Tuban, \\ email : dinahafni@stitmatuban.ac.id
}

\begin{abstract}
This research works for two reasons; first, academically, variative method will be highly effective and efficient in teaching quality. Meanwhile if this does not develop well, it is an obstacle for the achievement of learning objectives, the achievement of critical thinking skills. Second, based on the first observation, it was found that there are some social studies teacher who teach the student by speech method, asking-answer question, and giving works. It will not develop student critical thinking based on what FRISCO stated. The research purpose is to identify and analyze the learning method of social studies teacher in MIN Rejoso to developing student critical thinking skills. It is field research with qualitative approach. The data is collected by interview, observation, and document analysis. The data analysing technicque uses "discourses analysis". The research found is the method used by social studies teacher in MIN Rejoso Peterongan Jombang can not develop the student critical thinking skills. The causes is there are some teacher"s view that social studies is similar with rote and stories. The paradigm that may admit the teacher is everything, teachers is lazy to design critical learning due to lot of other works that must finished, and limited facilities.
\end{abstract}

Keywords: method of teaching, social studies teacher of Islamic elementary school, critical thinking

\section{Pendahuluan}

Mengaktualisasikan mata pelajaran Ilmu Pengetahuan Sosial (IPS) di Madrasah Ibtidaiyah (MI) menjadi sebuah pembelajaran yang bermakna bagi kehidupan sehari-hari merupakan tanggung jawab guru sebagai disainer pembelajaran. IPS menjadi titik penting diberikan secara bermakna karena nilai-nilai pendidikan IPS dibutuhkan langsung bagi kehidupan siswa sehari-hari.

Sebagaimana tertuang dalam Permendiknas Nomor 22 tahun 2006 dikatakan bahwa mata pelajaran IPS diberikan di sekolah dasar dengan tujuan agar peserta didik: 1) mengenal konsep-konsep yang berkaitan dengan kehidupan masyarakat dan lingkungannya; 2) memiliki kemampuan dasar untuk berfikir logis dan kritis, rasa ingin tahu, inkuiri, memecahkan masalah, dan keterampilan dalam kehidupan sosial; 3) memiliki komitmen dan kesadaran terhadap nilainilai sosial dan kemanusiaan; dan 4) memiliki kemampuan komunikasi, bekerjasama dan 
berkompetisi dalam masyarakat yang majemuk, di tingkat lokal, nasional, dan global. ${ }^{1}$ Melalui pendidikan, peserta didik diharapkan menjadi manusia yang dapat mengembangkan kemampuannya untuk memenuhi kebutuhan hidupnya sesuai dengan norma hukum yang berlaku. ${ }^{2}$

Metode mengajar guru IPS dalam penelitian ini diambil menjadi tema penting, didasari oleh dua hal. Pertama, metode pembelajaran yang variatif dan efektif akan mempertinggi kualitas pembelajaran. Maka tidak salah bila terdapat kata-kata Arab yang artinya "metode lebih penting daripada materi”. Kedua, pengorganisasian pembelajaran, termasuk pemilihan metode, apabila tidak dikembangkan secara beragam, menarik dan tepat, tidak mustahil akan menghambat pencapaian kompetensi.

Sedangkan berfikir kritis dalam penelitian ini diambil menjadi tema penting lainnya, didasari oleh tiga hal. Pertama, berfikir kritis adalah salah satu komponen pemberdayaan, dimana hal ini juga merupakan amanat Undang-undang Nomor 20 Tahun 2003 tentang Sistem Pendidikan Nasional pada bagian prinsip penyelenggaraan pendidikan, yang mengatakan bahwa pendidikan memiliki multimakna apabila proses pendidikan yang diselenggarakan berorientasi pada pembudayaan, pemberdayaan, pembentukan watak dan kepribadian, serta berbagai kecakapan hidup. ${ }^{3}$

Kedua, keluhan tentang rendahnya kemampuan berfikir (khususnya kemampuan berfikir kritis) yang dimiliki oleh lulusan pendidikan dasar. Karena dasar-dasar berfikir tersebut tidak dikuasai dengan baik, dampaknya dirasakan sampai pendidikan menengah dan pendidikan tinggi.

Ketiga, berfikir kritis tidak sama dengan mendebat atau mengecam orang lain. Berfikir kritis adalah kemampuan untuk berfikir jernih dan rasional, yang meliputi kemampuan untuk berfikir reflektif dan independen. Reflektif merupakan kegiatan berfikir yang teliti dan solutif, sedangkan independen lebih dekat dengan eksistensi diri yang mandiri dengan tidak "mengganggu" eksistensi orang lain.

Kegiatan belajar mengajar akan berlangsung efektif apabila siswa turut aktif dan berpartisipasi dalam sebuah pembelajaran. Jadi siswa ikut memberikan pendapat tentang materi yang diajarkan atau materi yang dipelajari dalam kegiatan pembelajaran. Kemudian guru juga

\footnotetext{
${ }^{1}$ Peraturan Menteri Pendidikan Nasional Republik Indonesia Nomor 22 Tahun 2006 tentang Standar Isi Untuk Satuan Pendidikan Dasar dan Menengah (Jakarta: Depdiknas, 2006). 125

${ }^{2}$ Latif, Isnawati Nur. (2020). Optimalisasi Lingkungan Pendidikan di Tengah Pandemi. Premier, Vol. 2 No. 1, 42-62

${ }^{3}$ Undang-Undang Nomor 20 Tahun 2003 tentang Sistem Pendidikan Nasional, BAB III pasal 4, 2008, Cet I, Jakarta: Asa Mandiri
} 
harus memberikan kesempatan kepada siswa untuk bertukar pikiran dengan temannya. Disamping itu juga guru harus mengawasi siswa dan mengarahkan siswa supaya ada timbal balik terjadi antara siswa dan guru.

Dalam pembelajaran khususnya IPS guru harus menciptakan suasana pembelajaran sesuai dengan kondisi, kemampuan siswa, dan perkembangan siswa dan menyadari bahwasanya belajar merupakan kegiatan aktif dalam membangun makna atau pemahaman supaya pembelajaran yang dilakukan betul-betul bermanfaat untuk siswa tersebut.

Pendidikan Ilmu Pengetahuan Sosial (IPS) sebagai bagian dari pendidikan ilmu pada umumnya, memiliki peranan sangat penting dalam menghasilkan peserta didik yang mampu berintraksi dalam kehidupan dengan baik, baik itu dalam masyarakat maupun keluarga.

Mata pelajaran Ilmu Pengetahuan Sosial (IPS) di Madrasah Ibtidaiyah (MI) adalah sebuah pembelajaran yang bermakna pada kehidupan sosial, khususnya kehidupan sehari-hari. Pembelajaran ini merupakan tanggung jawab pendidik atau guru. Ilmu Pengetahuan Sosial sebuah ilmu yang menjadi titik penting yang dibutuhkan dalam berintraksi social dan ini merupakan tanggung jawab guru sebagai seoarang perancang pembelajaran.

Dengan demikian, dapat dikatakan bahwa berfikir kritis sangat penting diajarkan pada kepada siswa tingkat dasar MI/SD, agar siswa memiliki kepekaan dan memiliki tanggung jawab sosial terhadap orang terdekatnya, oleh karnanya maka pembelajaran IPS di MI/SD harus diselenggarakan dengan metode-metode yang bisa merangsang dan mendorong siswa dalam keaktifan dan berfikir kritis, bukan dengan metode-metode konvensional yang sering dilakukan oleh guru-guru konvensional yang menonton dan menjamukan materi, yang membuat siswa menjadi seorang penonton dan pendengar yang pasif.

\section{Metode Pengajaran}

Metode merupakan suatu alat dalam pelaksanaan pendidikan, yakni yang digunakan dalam penyampaian materi pelajaran. Kata, teach atau mengajar yang berasal dari bahasa Inggris kuno, yaitu teacan, kata ini berasal dari bahasa Jerman kuno (old teutenic), taikjan yang berasal dari kata dasar teik yang berarti memperlihatkan. ${ }^{4}$

\footnotetext{
${ }^{4}$ Dodi, Limas. (2013). "Metode Pengajaran Nahwu Shorof (Ber-Kaca Dari Pengalaman Pesantren)." Tafaqquh: Jurnal Penelitian Dan Kajian Keislaman 1, no. 1. Fakhriyah, F. "Penerapan Problem Based Learning Dalam Upaya Mengembangkan Kemampuan Berpikir Kritis Mahasiswa.” Jurnal Pendidikan IPA Indonesia 3, no. 1 (2014): 95101.
} 
Pengajaran merupakan suatu upaya guru sebagai pendidik dalam memberikan keterampilan dan pengetahuan pada siswa. Metode pengajaran ialah cara yang digunakan untuk guru atau ustadz dalam mengadakan hubungan pada siswa saat berlangsungnya pengajaran, oleh karena itu peranan metode pengajaraan sebagai alat untuk menciptakan proses pengajaran dan belajar. ${ }^{5}$ Metode pengajaran merupakan cara yang berisi prosedur baku untuk melaksanakan kegiatan kependidikan, khususnya kegiatan penyajian materi pelajaran menunjukkan secara tulus tertarik pada mata kepada siswa.

\section{Ilmu Pengetahuan Sosial IPS}

Pembelajaran IPS adalah pembelajaran yang memungkinkan peserta didik bersama sama mencari, menggali, dan menemukan konsep serta prinsip secara holistik dan otentik. IPS mencakup materi dari geografi, sosiologi, sejarah, ekonomi dapat dibahas siswa dalam diskusi memecahkan masalah. ${ }^{6}$ Pendidikan IPS ialah penyederhanaan atau adaptasi dari disiplin ilmuilmu sosial dan humaniora, serta kegiatan dasar manusia yang. diorganisasikan dan disajikan secara ilmiah dan padagogis/psikologis untuk tujuan pendidikan. ${ }^{7}$

Tujuan mata pelajaran Ilmu Pengetahuan Sosial (IPS) di MI/SD yaitu Pertama, Mengenal konsep-konsep yang berkaitan dengan kehidupan masyarakat dan lingkungannya. Kedua, Memiliki kemampuan dasar untuk berpikir logis dan kritis, rasa ingin tahu, inquiri, memecahkan masalah, dan keterampilan dalam kehidupan sosial. Ketiga, Memiliki komitmen dan kesabaran terhadap nilai-nilai sosial dan kemanusiaan. Keempat, Memiliki kemampuan berkomunikasi, bekerjasama dan berkompetisi dalam masyarakat yang majemuk, di tingkat lokal, nasional, dan global. $^{8}$

Berdasarkan tujuan mata pelajaran IPS di SD/MI siswa diharapkan mampu menyadari gejala sosial yang dihadapi dan memiliki kemampuan menyelesaikan secara logis sesuai dengan nilai-nilai sosial kemanusian. Konsep-konsep gejala sosial bersifat abstrak sehingga harus

\footnotetext{
${ }^{5} \operatorname{Ibid}(4)$

${ }^{6}$ Hermanu Joebagio. Supanti. dkk. (2017). "Penerapan Model Problem Based Learning ( PBL ) Dalam Pembelajaran Ips Dengan Media Visualisasi Museum Gula Gondang Winangun Untuk Meningkatkan Kemampuan Berpikir Kritis Siswa Kelas VII H Smp Negeri 1 Surakarta.” Historika: 15-23.

${ }^{7}$ Hidayah, Nurul, and Rifky Khumairo Ulva. (2017). "Pengembangan Media Pembelajaran Berbasis Komik Pada Mata Pelajaran Ilmu Pengetahuan Sosial Kelas IV MI Nurul Hidayah Roworejo Negerikaton Pesawaran.” Terampil Jurnal Pendidikan Dan Pembelajaran Dasar 4, no. 1: 34-46.

${ }^{8}$ Sapriya. (2009). Pendidikan IPS. Bandung: Rosdakarya
} 
disosialisasikan dalam kegiatan pembelajaran. Keabstrakan konsep-konsep materi IPS menjadi hambatan belajar siswa dalam menguasai konsep (materi) tersebut. ${ }^{9}$

\section{Berfikir Kritis}

Berpikir adalah kemampuan untuk menganalisis, mengkritik, dan mencapai kesimpulan berdasar pada inferensi atau pertimbangan yang saksama. Baker (1991) menjelaskan berpikir kritis digunakan seseorang dalam proses kegiatan mental. Sedangkan menurut Ennis (2011) bahwa berpikir kritis merupakan berpikir logis atau masuk akal yang berfokus pada pengambilan keputusan tentang yang dipercaya dan dilakukan seseorang. ${ }^{10}$

Berpikir kritis merupakan berpikir menggunakan penalaran, berpikir reflektif, bertanggung jawab, dan expert dalam berpikir. Jadi berpikir kritis merupakan aktivitas mental seseorang dalam mengumpulkan, mengkategorikan, menganalisa, dan mengevaluasi informasi ataupun bukti agar dapat membuat suatu simpulan untuk memecahkan masalah.

Kemampuan berpikir kritis setiap individu berbeda-beda, tergantung pada latihan yang sering dilakukan untuk mengembangkan berpikir kritis. Berpikir kritis bersifat reasonable dan berpikir reflektif yang difokuskan pada memutuskan apa yang harus dipercayai dan apa yang harus dilakukan. Artinya ketika menggunakan berpikir kritis akan dapat memutuskan dengan tepat apa yang seharusnya dipercayai dan apa yang harus dilakukan. ${ }^{11}$

Karakteristik kemampuan berpikir kritis menurut Carin dan Sound dibagi menjadi beberapa kategori diantaranya yaitu mengklasifikasi, mengasumsi, berhipotesis, membuat kesimpulan, mengukur, merancang sebuah penyelidikan, mengamati, membuat grafik, meminimalkan kesalahan percobaan, mensintesis, mengevaluasi, dan menganalisis. ${ }^{12}$

Tujuan berpikir kritis diajarkan kepada siswa antara lain agar siswa dapat belajar memecahkan masalah secara sistematis, inovatif, dan mampu mendesain alternatif solusi yang mendasar.

\footnotetext{
${ }^{9}$ Natriani, Syam \& Ramlah Ramlah.(2015). "Penerapan Model Pembelajaran Mind Mapping Dalam Meningkatkan Hasil Belajar Pada Mata Pelajaran Ilmu Pengetahuan Sosial Siswa Kelas Iv Sdn 54 Kota Parepare,” Publikasi Pendidikan 5, no. 3 hlm 184

${ }^{10}$ Amir, Mohammad Faizal. (2017). "Proses Berpikir Kritis Siswa Sekolah Dasar Dalam Memecahkan Masalah Berbentuk Soal Cerita Matematika Berdasarkan Gaya Belajar.” Jurnal Math Educator Nusantara 01, no. 02 hlm 160,

${ }^{11}$ Nafiah, Yunin Nurun \& Wardan Suyanto.(2014). "Penerapan Model Problem-Based Learning Untuk Meningkatkan Keterampilan Berpikir Kritis Dan Hasil Belajar Siswa,” Jurnal Pendidikan Vokasi 4, no. 1 hl. 148

${ }^{12}$ Lukitasari, Dian Retno. (2013). Upaya Meningkatkan Kemampuan Berpikir Kritis Siswa Melalui Model Pembelajaran Berbasis Masalah Dengan Berbantuan Film Sebagai Sumber Belajar. Skripsi UNNES Semarang
} 


\section{Metodologi}

Pendekatan yang digunakan dalam penelitian ini adalah penelitian kualitatif. Penelitian yang dilakukan merupakan penelitian kepustakaan (Library Research). Menurut Ratna dalam bukunya Prastowo mengemukakan bahwa metode kepustakaan ialah metode penelitian yang pengumpulan datanya dilakukan melalui tempat-tempat penyimpanan hasil penelitian yaitu perpustakaan. ${ }^{13}$ Riset pustaka atau sering juga disebut studi pustaka adalah serangkaian kegiatan yang berkenaan dengan metode pengumpulan data pustaka, membaca dan mencatat serta mengolah bahan penelitian. ${ }^{14}$ Tempat penelitian diakukan di perpustakaan UIN Sunan Kaijaga Yogyakarta. Waktu penelitian dari bulan Maret-Mei 2020.

Data dari penelitian ini merupakan data "mati". Artinya data tersebut tidak akan pernah berubah karena tersimpan dalam rekaman tertulis. Dalam penelitian ini sumber data yang digunakan ada dua yaitu sumber data primer dan sumber data sekunder. Dalam penelitian ini, data sekunder didapatkan dari beberapa buku, jurnal, surat kabar online, serta artikel yang berkaitan dengan objek penelitian. Subjek penelitiannya adalah buku atau jurnal mengenai metode pengajaran IPS MI untuk meningkatkan kemampuan berfikir kritis siswa. Teknik pengumpulan data menggunakan studi pustaka dan dokumentasi. Teknik pengecekan keabsahan data menggunakan metode triangulasi. Teknik analisis data menggunakan kajian isi (content analysis).

Adapun data yang dihimpun terdiri atas data primer dan data sekunder. Data primer adalah suatu dokumen original dari pelaku yang disebut first-hand information. Data sekunder ialah data yang diperoleh dari tangan kedua, yang disebut second-hand information atau data dari sumber lain yang telah tersedia sebelum penelitian dilakukan.

Penelitian ini mengambil data dari sumbernya yang terkandung dalam 3-p; person (sumber data berupa orang), place (sumber data berupa tempat), dan paper (sumber data berupa dokumen: huruf, angka, gambar, atau simbol-simbol lain yang digunakan untuk dokumentasi). ${ }^{15}$

Sedangkan teknik pengumpulan data dalam penelitian ini adalah dengan wawancara mendalam, pengamatan berperan serta, dan kajian dokumen. Dan teknik yang digunakan dalam menganalisis data pada penelitian ini adalah analisis diskursif (discourses analysis). Teknik

\footnotetext{
${ }^{13}$ Prastowo, Andi. (2011). Metode Penelitian Kualitatif Dalam Perspektif Rancangan Penelitian (Yogyakarta: ArRuzz Media), hlm 190

${ }^{14}$ Zed, Mustika. (2004). Metode Penelitian Kepustakaan. Cet-1. Jakarta: Yayasan Obor IndonesiaCE, hlm 3

${ }^{15}$ Arikunto, Suharsimi. (2006) Prosedur Penelitian, Suatu Pendekatan Praktik. Cet XIII (Jakarta: Rineka Cipta hal. 129.
} 
analisis data ini digunakan untuk menganalisis bentuk-bentuk wacana yang memuat rangkaian pemikiran yang dapat direkonstruksi dengan cara yang berbeda-beda, dan menangkap fenomena atau gejala yang muncul dari obyek yang diteliti secara profesional, optimal, dan bertanggungjawab. Selanjutnya peneliti memberikan interpretasi terhadap gejala tersebut. ${ }^{16}$

\section{Konsep Mengajar}

Dalam persepektif tarbiyah, mengajar yaitu kegiatan memberikan ilmu yang dimiliki oleh seorang guru kepada muridnya. Dalam beberapa pendapat, di dalam kitab taklim muta'allim tarbiyah disetarakan dengan mendidik. Namun demikian, mengajar lebih dulu ada dari pada mendidik, Hal ini dapat dilihat dari sejarah Rosulullah yang memberikan pengajaran kepada sahabat dan kerabat-Nya.

Dalam mengajar, merupakan tugas seorang guru 24 juga dalam membantu peserta didik (siswa) 25 peserta didik adalah manusia yang belum dewasa, oleh karna itu dia membutuhkan pengajaran, pelatihan bimbingan dari orang dewasa atauu bisa dikatakan dengan menggunkana bahasa yang lebih terkenal dan tekhnis adalah "pendidik" dengan tujuan untuk mematangkan diri menuju sebuah kehidupan yang lebih baik.

Burton mengemukakan batasan mengajar dengan mengatakan bahwa "Teaching is the stimulation, guidance, direction and encouragment of learning". Guru konsevatif yaitu guru yang pasrah pada keadaan, tidak mau mengubah kondisi yang ada, dan hanya menempatkan situasi yag dihadapi sebagai suatu yang diterima tanpa dianggap sebagai produk sosial yang bisa diubah. ${ }^{17}$

Mengenai guru konservatif maka bisa dilihat beberapa ciri dalam dunia pendidikan, yaitu:

a. Guru hanya larut dalam ritualitas mengejar tanpa menjadikan semngat perubahan terpatri dalam pikirannya, mengubah jepribadian siswa dan selanjutnya mengubah sistem social menjadi lebih baik.

b. Guru memandang bahwa posisinya sebagai guru adalah posisi yang elit, yang dapat digunakan untuk mendapatkan prestise dan rasa hormat dari orang lain.

\footnotetext{
${ }^{16}$ Ibid (15)

${ }^{17}$ Batubara, Abdinur, and Cecep Darmawan. (2017). "Revitalisasi Paradigma Konservatif Pendidikan Demokrasi Pada Pkn Dengan Inovasi Media Pembelajaran.” Jurnal Ilmiah Pendidikan Pancasila Dan Kewarganegaraan 2, no. 2: $81-84$.
} 
c. Guru tidak mengembangkan dan memperbaharui metode-metode dan praktik pengajaran yang membuat siswa memudahkan memperdayakan dan meningkatkan kualitas dirinya dan siswanya, tetapi hanya berpatok pada gaya pengajaran lama yang anti dialogis.

d. Guru memandang murid sebagai objek yang bisa dicoba dengan pengetahuan semata dan bukan subjek yang punya penglamana dan latar belakang yang berbeda-beda, dan kemudian dianggap sebagai manusia yang memiliki dunianya yang harus berubah.

e. Guru dengan metode yang baik atau menggunakan gaya pendidikan yang diistilahkan oleh Paulo Freire "pendidikan gaya bank". ${ }^{18}$

Sedangkan karakter guru yang progresif yaitu mereka yan bertolak belakang dengan karakter konservatif sebagai mana telah disebutkan diatas. Dalam batin dan benak guru konservatif hanya ada cara bagaiman mengubah kondisi sosial melalui perubahan kesadaran yang dialami siswa dan menyadari bahwa proses pendidikan adalah upaya untuk mengubah bagaimana realitas yang berbentuk dalam kesadaran siswa. Ia adalah seorang guru yang berupaya mengubah bagaiman proses berfikir siswa dan menganggap pengetahuan itu penting, akan tetapi yang lebih penitng adalah menggunakan pengetahuan untuk perubahan siswa.

\section{Konsep Metode}

Dalam proses pendidikan, metode mempunyai kedudukan sangat signifikan untuk mencapai sebuah tujuan pembelajaran. Bahkan metode adalah sebuah seni sebagai mentransfer sebuah ilmu pengetahuan kepada peserta didik yang diajarkan dan peserta didik dianggap lebih signifikan dibanding dengan materi sendiri. Sebuah adigium mengatakan bahwa 'al-Thariqat Ahamm Min al-Maddah, yang mengandung arti "metode jauh lebih penting dibanding materi”, adalah sebuah realitas, bahwa cara penyampaian yang komunikatif jauh lebih efektif dan disenangi oleh peserta didik walaupun materi yang disampaikan sesungguhnya tidak terlalu menarik. Sebaliknya, materi yang cukup baik, karena disampaikan dengan cara yang kurang menarik maka materi itu sendiri menjadi kurang dapat dicerna oleh peserta didik. Oleh karnanya penerapan metode yang tepat sanagat bepengaruh terhadap kepahaman siswa dalam sebuah

\footnotetext{
${ }^{18}$ Murtianingsih, Siti. (2004). Pendidikan Alat Perlawanan. Yogyakarta: Resist Book. Hal 23.
} 
proses pembelajaran, sementaranya penggunakan metode yang tidak tepat akan berpangaruh kepada peserta didik dan akan manghabiskan waktu yang tidak efisien pula. ${ }^{19}$

Dalam menjalankan tugas mengajar, guru membutuhkan metode sebagai upaya mereflektifkan dan mengefesiensikan pembelajaran menjadi lebih mudah, meyenangkan dan cepat dicerna oleh siswa, selanjutnya pula tujuan pembelajaran mudah dicapai dan diuraikan secara detail. Mengajar juga adalah pengambilan keputusan, dan pembuatan keputusan yang tepat dan memerlukan diagnosis yang baik. Tanpa keputusan yang tepat atau diagnosis yang tepat, guru cendrung mengajar apa saja dengan cara yang sama terhadap siswa, dan sebagai akibatnya pegajaran menjadi membosankan, menimbulkan frustasi dan ketidakberhasilan. ${ }^{20}$

Ada beberapa variabel yang menjadi tantangan guru dalam mendiagnosis pengajaran itu sendiri yaitu: (a) tujuan yang dicari, (b) siswa yang akan diajar, (c) meteri yang diajarkan, (d) tekhnologi dan alat yang tersedia, (e) sifat dan dinamika kelompok yang diajar. Agar metode berfungsi dengan baik, efektif dan efisien, maka guru harus mempertimbangkan hal-hal berikut: $^{21}$

a. Keadaan siswa yang mencangkup pertimbangan tentang tingkat kecerdasan, kematangan, perbedaan individu, dan lainnya.

b. Tujuan ynag hendak dicapai, jika tujuannya berada pada ranah kognitif.

c. Situasi yang mencakup hal-hal seperti kelas, situasi lingkungan (lingkungan yang sangat mendukung).

d. Alat-alat yang tersedia dan bisa digunakan.

e. Kemampuan mengajar, mencakup kemampuan fisik, keahlian. Semisal metode demonstrasi yang membutuhkan keahliah khusus dan memrlukan tingkat kepekaan yang sangat tinggi.

f. Sifat bahan pengajaran.

${ }^{19}$ Fikri, Mumtazul. (2017). “KONSEP PENDIDIKAN ISLAM; Pendekatan Metode Pengajaran.” Jurnal Ilmiah Islam Futura 11, no. 1 (2017). Hal 116.

${ }^{20}$ Rianie, Nurjannah. (2015). Pendekatan Dan Metode Pendidikan Islam (Sebuah Perbandingan Dalam Konsep Teori Pendidikan Islam Dan Barat). Jurnal: Management of Education 1, no. 2 (2015): 107.

${ }^{21}$ Mukrimah, Sifa Siti. (2014). 53 Metode Belajar Dan Pemngajaran Plus Aplikasinya Bandung: Bumi Siliwangi. Hal 12 


\section{Metode Mengajar Kritis IPS MI (Mengembangkan Keterampilan Berfikir Kritis)}

Metode memiliki arti yang sangat penting yang lebih dari sekedar alat untuk menyampaikan ilmu pada peserta didik, akan tetapi juga membantu peserta didik memperoleh pengajaran dan pembelajaran. Keberadaan metode ini juga sangat bermanfaat sebagai alat untuk menolong para pelajar untuk mendapatkan keterampilan-keterampilan sikap, minat,dan nilainilai yang diinginkan oleh siswa. ${ }^{22}$

Ciri sangat dominan bagi pembelajaran IPS sebagai mata pelajaran pendidikan dasar yaitu sifat terpadu dari sekian jumlah pelajaran dengan bertujuna agar mata pelajaran lebih bermakna bagi siswa sehingga pengelompokkan mata pelajaran disesuaikan dengan lingkungan, krebutuhan, dan karakteristik, dan kebutuhan siswa. Kebermaknaan ini sangat penting bagi siswa, baik sebagai individual maupun sebagai masyarakat pada umumnya.

Untuk itulah pengajaran IPS MI tidak bisa dilakukan dengan sekedarnya, tetapi sebaliknya harus dibarengi dan didukung oleh metode-metode yang menarik yang bias meningkatkan gairah peserta didik untuk belajar dan mendukung pencapaian yang bermakna bagi siswa. Kebermaknaan akan dirasakan oleh siswa yang terlibat aktif dalam proses belajarnya, proses berfikir dan bertindak.

Mengajar yang berhasil, menuntut menggunakkan metode yang tepat. Seorang guru tentu mempunyai metode yang tepat dan jitu yang cepat dan tangkap bisa dipahami oleh siswa, namu kalau dilhat tidak ada satu pun metode yang terbaik untuk semua pelajaran. ${ }^{23}$ Karna membantu siswa melalui sebuah metode unutk berfikir kritis dam kreatif merupakan salah satu tujuan diajarkannya IPS di MI. berfikir kritis digunakan dalam berbagai situasi dan kesempatan dalam berbagai memecahkan peroslan kehidupan.

Berfikir kritis yaitu suatu keterampilan yang didapatkan melalui proses, bukan merupakan sifat yang diwariskan orang tua kepada anaknya. Oleh karnanya perlu ada upaya untuk mengajarkan tentang cara berfikir kritis kepada siswa sedini mungkin agar mereka terbiasa dalam melakukam pemecahan masalah yang sulit.

Para ahli pendidikan ada yang menulis dan menetapkan sifat-sifat metode mengajar yang baik. ${ }^{24}$ Sifat-sifat yang dimaksud yaitu pertama, teliti/cermat dan sungguh-sungguh yaitu metode mengajar harus didasarkan pada ketelitian yang bersifat ilmiah. Kedua, artistic, Guru dituntut

\footnotetext{
${ }^{22}$ Khoiron, Rosyadi. (2004). Pendidikan Profetik Profetik. Yogyakarta: Pustaka Pelajar. Hal 210.

${ }^{23}$ Alamsyah Said, dan Andi Budimanjaya. (2017). Strategi Mengajar. Cetakan ke. Jakarta: KENCANA Hal. 16

${ }^{24}$ Wahab, Abdul Aziz. (2007). Metode Dan Model-Model Mengajar IPS. Bandung: Alfabeta Hal 36-48
} 
untuk memiliki sebuah rasa kesesuaian dan tidak kesesuian. Guru harus menyadari tentang perspektif dan proposal. Kekosongan fakta tidak sama dengan kebenaran. Dengan metode yang dimiliki oleh seorang guru, guru dituntut untuk mensintesakan dan menafsirkan. Ketiga, bersifat pribadi. Metode mengajar harus direncanakan, disusun, dan dikembangkan guru sendiri dengan didasarkan pada pemahaman ilmiah, yang jauh dari basa basi dan tindakan yang sekedarnya. Keempat, metode yang berhubungan dengan kepahaman siswa. Pada dasarnya metode mengajar tidak hanya berkaitan dengan guru melainkan dari siswa juga dikarnakan metode merupakan elemen dalam suatu proses intraksi edukasi. ${ }^{25}$

Praktik pengajaran berfikir kritis dilakukan dengan menjelaskan dan menghubungkan fakta-fakta yang ada, mengkonstruksi fakta-fakta dan atribut-atribut menjadi suatu konsep yang akan melahirkan generalisasi. Dengan kebiasaan terampil membangun kosntruk, siswa akan terampil pula mencermati permasalahan dan cakap menemukan beragai alternatif pemecahannya. Hingga pada akhirnya, tidak mustahil siswa akan lebih siap menghadapi tantangan kehidupan yang lebih kompleks.

Berikut ini beberapa konsep yang bisa dijadikan sebagai dasar pemilihan metode mengajar IPS MI :

a. Mengajarkan bagaimana memahami

Pengajaran memahami diperlukan untuk merumuskan konsep-konsep, dimana konsepkonsep tersebut bersifat abstrak. Setiap konsep muncul dalam pikiran seseorang sebagai pemahaman terhadap sesuatu. Berikut ini hal-hal yang perlu diperhatikan dalam pengajaran konsep yaitu :

1) Berkaitan dengan pengalaman.

Guru tidak bisa memberikan pengertian pada siswa hanya dengan melalui eksposis sederhana. Siswa belajar konsep melalui perbuatan, guna memperoleh konsep. Yang perlu dilakukan pertama-tama adalah memilih sejumlah pengalaman dan menyusunnya dalam pikiran. Pengalaman yang dimaksud bukan hanya yang bersifat intelektual melainkan juga emosi, rasa, dan kegiatan fisik.

\footnotetext{
${ }^{25}$ Nugraha, Widdy Sukma. (2018). Peningkatan Kemampuan Berpikir Kritis Dan Penguasaan Konsep IPA Siswa SD Dengan Menggunakan Model Problem Based Learning," EduHumaniora | Jurnal Pendidikan Dasar Kampus Cibiru 10, no. 2 (2018): 116.
} 
2) Hindari ketergantungan yang besar pada kegiatan verbal.

Konsep tidak dipelajari hanya dengan kata-kata. Ketergantungan pada kata-kata belaka akan menimbulkan verbalisme dan bukan pemahaman. Untuk itu gunakan sebanyak mungkin kegiatan belajar bermain peran, bahan alat pandang dengar, diskusi, kegiatan mengkonstruksi, dan banyak lagi, sebelum siswa mulai membangun pemahaman yang jelas tentang konsep yang diinginkan.

3) Uraikan pengertian resmi konsep secara jelas.

Adalah tidak cukup jika siswa hanya dapat menjelaskan konsepnya secara pribadi, tetapi sebaliknya ia pun dapat menjelaskan pengertian resmi tentang suatu konsep dengan bahasanya sendiri dan dengan memberikan beberapa contoh.

4) Gunakan cara-cara yang bisa mengungkapkan, misalnya :

- Tanyakan kepada siswa apa yang ia maksud dengan kata-kata sendiri.

- Tanyakan kepada siswa untuk menggambarkan atau mendemonstrasikan pengertiannya.

- Kembalikan pemikiran siswa kembali kepadanya, mungkin menyusunnya kembali dan menanyakan apa yang dimaksud sebenarnya.

- Tanyakan tentang akibat atau implikasi logis dari gagasannya.

- Minta siswa merangkum atau meringkas agar dapat diangkat bagian-bagian yang penting.

- Minta kepada siswa untuk menyusun pemahamannya ke dalam garis-garis besar secara logis.

5) Gunakan teknik menemukan sendiri.

Guru-guru yang kritis dan kreatif selalu mendasarkan mengajarnya pada pertanyaanpertanyaan, contoh-contoh, dan perumpaman (parables). Pertanyaan, contoh, dan perumpamaan digunakan sebagai alat membantu siswa dalam proses menemukan sendiri (discovery) konsep-konsep.

6) Berikan kesempatan kepada siswa untuk membentuk konsep dan generalisasi sendiri melalui kesimpulan induktif dan deduktif. 
7) Tunjukkan elemen pokok.

Pendekatan apapun yang digunakan dalam mengajarkan konsep, harus diyakini bahwa bagian-bagian penting Nampak jelas (conspicuous). Jelaskan secara verbal dan visual,menggunakan petunjuk dan pertanyaan-pertanyaan pokok.

8) Gunakan apa yang disebut dengan advance organizer.

Meramu lebih lanjut suatu masalah (advance organizer) merupakan salah satu pendekatan penting dalam mengajarkan konsep. Di dalam AO ini guru membantu siswa dengan dasar-dasar tempat menggantungkan fakta-fakta dan konsep yang akan dipelajari siswa. Hal itu harus dapat membantu siswa untuk menghubungkan yang baru dipelajari dengan yang sudah dipelajari.

9) Membantu perkembangan berfikir berbeda (divergent thinking) yang orisinil.

10) Tumbuhkan sikap kritis terhadap konsep sendiri.

Bertanya secara socratic (filosofis-kritis) yang mengenalkan informasi yang tidak sesuai dengan keyakinan yang sudah disusun terlebih dahulu (preset belief) merupakan terknik terbaik dalam menghasilkan sikap kritis.

11) Tumbuhkan keberanian pada siswa untuk menguji generalisasi yang telah dirumuskan.

b. Mengajarkan sikap dan nilai

Berbeda dengan pengajaran konsep dan generalisasi, maka mengajarkan sikap dan penghargaan, sesuatu yang ideal, minat, nilai-nilai, karakter, moral, dan etika adalah lebih sulit. Namun karena hal itu merupakan kebutuhan bangsa dan negara, maka harus tetap diajarkan sebagai tanggung jawab dan mengajarkannya secara efektif.

1) Mengembangkan sikap.

Cara-cara mengembangkan sikap bisa dilakukan dengan berbagai cara antara lain: pertama, mengenali sebuah model dan meniru perilaku model tersebut. Kedua, melalui pengalaman emosional. Ketiga, melalui perolehan informasi. Keempat, melalui sikap ideal yang telah disiapkan untuk diikuti secara terus- menerus sampai menjadi suatu kebiasaan.

2) Mengembangkan sikap menghargai dan minat.

Menghargai dan minat adalah bentuk khusus dari kelompok sikap. Dalam upaya mengembangkan apresiasi dan minat, yang harus diberikan perhatian khusus adalah sentuhan afeksi terhadap penyajian dan contoh-contoh yang harus diikuti oleh siswa. 
3) Mengembangkan nilai-nilai.

Apabila guru ingin mengembangkan nilai-nilai pada siswa maka lebih baik:

- Memberikan kemungkinan kepada siswa untuk memilih secara bebas.

- Membantu menemukan dan menguji berbagai alternatif bila dihadapkan dengan pilihan.

- Memantu siswa untuk menimbang pilihan-pilihan yang ada secara hati-hati dan mencoba membayangkan akibat-akibat yang mungkin ditimbulkannya.

- Mendorong siswa untuk mempertimbangkan sesuatu yang diberi dianggap bernilai dan yang dihargai.

- Beri kesempatan pada siswa untuk menjelaskan kepada teman-teman lainnya tentang pilihan mereka.

- Bantu siswa untuk bertindak, hidup dan berperilaku sesuai dengan pilihannya.

- Berikan kemungkinan kepada siswa untuk menguji atau mengkaji ulang perilaku atau pola-pola perilaku dalam kehidupannya.

c. Mengajarkan bagaimana berfikir

Membantu siswa bagaimana berfikir kritis dan kreatif merupakan salah satu tujuan diajarkannya IPS di MI. Berfikir kritis digunakan dalam berbagai situasi dan kesempatan dalam upaya memecahkan persoalan kehidupan. Berfikir kritis adalah sebuah keterampilan yang didapatkan melalui proses, bukan merupakan sifat yang diwariskan orang tua kepada anaknya. Untuk itu perlu adanya upaya untuk mengajarkan tentang bagaimana beripikir kritis kepada siswa di sekolah sedini mungkin.

Untuk mengajarkan keterampilan berfikir kritis dapat dilakukan dengan berbagai metode. Terutama metode yang sifatnya memberikan kesempatan luas bagi siswa untuk melakukan aktualisasi dan eksplorasi diri, misalnya metode eksperimen, diskusi, inkuiri terbimbing, karya wisata, simulasi, debat, dan bermain peran.

\section{Pentingnya Mengembangkan Berfikir Kritis Siswa}

Telah disampaikan di atas bahwa berfikir kritis merupakan bagian penting dari aspek kehidupan seseorang, termasuk siswa. Oleh karena itu harus ada perubahan paradigma mengajar guru dari hanya memberikan informasi menjadi mengajarkan cara mencari informasi dan 
mempergunakannya untuk hal-hal lain yang bermanfaat. Berfikir kritis adalah berlatih atau memasukkan penilaian atau evaluasi yang cermat, seperti menilai kelayakan suatu gagasan atau produk.

Praktik mengajarkan berfikir kritis dilakukan dengan menjelaskan dan menghubungkan fakta-fakta, mengkonstruksi fakta-fakta dan atribut-atribut menjadi sebuah konsep dan menghubungkan antar konsep yang akan melahirkan generalisasi. Dengan menghubungkan berbagai generalisasi akan menghasilkan konstruk. Dengan kebiasaan terampil membangun konstruk, siswa akan terampil pula mencermati permasalahan dan cakap menemukan berbagai alternatif pemecahannya. Dan pada akhirnya, tidak mustahil siswa akan lebih siap menghadapi tantangan kehidupan yang lebih kompleks.

\section{Kesimpulan}

Dari pembahasan di atas maka dapat ditarik kesimpulan bahwa dalam mengajarkan suatu pembelajaran guru harus mempunyai metode yang jitu dan keren dalam mengajarkan suatu pembelajaran khususnya dimata pelajaran IPS dikarnakan didalam mata prlajaran IPS menyangkut di dalamnya pembelajaran social, yang menuntut agar siswa memeliki kepekaan dan mampu beradaptasi dengan lingkungan, baik itu dalam masyarakat maupun keluarga.

Praktik pengajaran IPS dalam suatu pembelajaran yang dilakukan dengan menjelaskan dan menghubungakan fakta-fakta yang ada, mengkonstruksi fakta-fakta dan atribut menjadi suatu konsep yang akan melahirkan generalisasi. Dengan kebiasaan trampil membangun suatu konstruk pengajaran, dan siswa trampil pula mecermati pemasalahan yang ada dan menemukan solusi dari permasalahn tersebut.

\section{Daftar Referensi}

Alamsyah Said, dan Andi Budimanjaya. (2017). Strategi Mengajar. Cetakan ke. Jakarta: KENCANA

Amir, Mohammad Faizal. (2017). "Proses Berpikir Kritis Siswa Sekolah Dasar Dalam Memecahkan Masalah Berbentuk Soal Cerita Matematika Berdasarkan Gaya Belajar." $\begin{array}{lllll}\text { Jurnal Math } \quad \text { Educator Nusantara } & 01\end{array}$ http://ojs.unpkediri.ac.id/index.php/matematika/article/download/235/150.

Arikunto, Suharsimi. (2006) Prosedur Penelitian, Suatu Pendekatan Praktik. Cet XIII (Jakarta: Rineka Cipta 
Batubara, Abdinur, and Cecep Darmawan. (2017). "Revitalisasi Paradigma Konservatif Pendidikan Demokrasi Pada Pkn Dengan Inovasi Media Pembelajaran.” Jurnal Ilmiah Pendidikan Pancasila Dan Kewarganegaraan 2, no. 2: 81-84. https://doi.org/10.17977/um019v2i22017p081.

Choiro, Umu Da'watul. (2019). Peran Lembaga Pendidikan Dalam Peningkatan Kualitas Guru Pendidikan Anak Usia Dini. Premiere, Vol. 1 No. 2, 35-42

Dewi, Candra. (2015). "Penerapan Model Pembelajaran Kooperatif Tipe Think- Pair-Share Untuk Meningkatkan Pemahaman Konsep Masala Sosial IPS Pada Siswa Sekolah Dasar" 5 Nomor 5: 155-67.

Dodi, Limas. (2013). "Metode Pengajaran Nahwu Shorof (Ber-Kaca Dari Pengalaman Pesantren)." Tafaqquh: Jurnal Penelitian Dan Kajian Keislaman 1, no. 1. Fakhriyah, F. "Penerapan Problem Based Learning Dalam Upaya Mengembangkan Kemampuan Berpikir Kritis Mahasiswa." Jurnal Pendidikan IPA Indonesia 3, no. 1 (2014): 95-101. https://doi.org/10.15294/jpii.v3i1.2906.

Fikri, Mumtazul. (2017). "KONSEP PENDIDIKAN ISLAM; Pendekatan Metode Pengajaran." Jurnal Ilmiah Islam Futura 11, no. 1 (2017): 116. https://doi.org/10.22373/jiif.v11i1.66.

Hermanu Joebagio. Supanti. dkk. (2017). "Penerapan Model Problem Based Learning ( PBL ) Dalam Pembelajaran Ips Dengan Media Visualisasi Museum Gula Gondang Winangun Untuk Meningkatkan Kemampuan Berpikir Kritis Siswa Kelas VII H Smp Negeri 1 Surakarta." Historika: 15-23.

Hidayah, Nurul, and Rifky Khumairo Ulva. (2017). "Pengembangan Media Pembelajaran Berbasis Komik Pada Mata Pelajaran Ilmu Pengetahuan Sosial Kelas IV MI Nurul Hidayah Roworejo Negerikaton Pesawaran." Terampil Jurnal Pendidikan Dan $\begin{array}{lllll}\text { Pembelajaran } & \text { Dasar } & \text { 4, } & \text { no. } & \text { 34-46. }\end{array}$ http://ejournal.radenintan.ac.id/index.php/terampil/article/view/1804.

Khoiron, Rosyadi. (2004). Pendidikan Profetik Profetik. Yogyakarta: Pustaka Pelajar.

Lukitasari, Dian Retno. (2013). Upaya Meningkatkan Kemampuan Berpikir Kritis Siswa Melalui Model Pembelajaran Berbasis Masalah Dengan Berbantuan Film Sebagai Sumber Belajar. Skripsi UNNES Semarang

Latif, Isnawati Nur. (2020). Optimalisasi Lingkungan Pendidikan di Tengah Pandemi. Premiere, Vol. 2 No. 1, 42-62

Mukrimah, Sifa Siti. (2014). 53 Metode Belajar Dan Pemngajaran Plus Aplikasinya Bandung: Bumi Siliwangi.

Murtianingsih, Siti. (2004). Pendidikan Alat Perlawanan. Yogyakarta: Resist Book.

Nugraha, Widdy Sukma. (2018). Peningkatan Kemampuan Berpikir Kritis Dan Penguasaan Konsep IPA Siswa SD Dengan Menggunakan Model Problem Based Learning," EduHumaniora | Jurnal Pendidikan Dasar Kampus Cibiru 10, no. 2 (2018): 116. 
Prastowo, Andi. (2011). Metode Penelitian Kualitatif Dalam Perspektif Rancangan Penelitian Yogyakarta: Ar-Ruzz Media

Rianie, Nurjannah. (2015). Pendekatan Dan Metode Pendidikan Islam (Sebuah Perbandingan Dalam Konsep Teori Pendidikan Islam Dan Barat). Jurnal: Management of Education 1, no. 2 (2015): 107.

Wahab, Abdul Aziz. (2007). Metode Dan Model-Model Mengajar IPS. Bandung: Alfabeta 